\title{
A thermal dehydration study of $\mathrm{WO}_{3} \cdot 2 \mathrm{H}_{2} \mathrm{O}$
}

\author{
S AYYAPPAN* and N RANGAVITTAL \\ Materials Research Centre and Solid State and Structural Chemistry Unit, \\ Indian Institute of Science, Bangalore 560 012, India \\ (Communicated by Professor C N R Rao) \\ MS received 20 August 1996
}

Abstract. Step-wise thermal dehydration of $\mathrm{WO}_{3} \cdot 2 \mathrm{H}_{2} \mathrm{O}$ has been investigated and the various hydrated tungsten trioxide phases characterized. A cubic phase of tungsten trioxide with 0.36 moles of water is obtained by heating $\mathrm{WO}_{3} \cdot 2 \mathrm{H}_{2} \mathrm{O}$ to $498 \mathrm{~K}$.

Keywords. Thermal dehydration; tungsten trioxide dihydrate; cubic phase.

\section{Introduction}

Solid state reactions which are topochemically controlled bear orientational relationship between the parent and product phases. Except for changes in dimension in one or more directions, the atomic arrangement in the reactant crystal remains largely unaffected during the course of a topotactic solid state reaction(Rao and Raveau 1995). Gunter (1972) showed that one such reaction is the dehydration of $\mathrm{MoO}_{3} \cdot 2 \mathrm{H}_{2} \mathrm{O}$ and $\mathrm{WO}_{3} \cdot 2 \mathrm{H}_{2} \mathrm{O}$ to give $\mathrm{MoO}_{3}$ and $\mathrm{WO}_{3}$ respectively. The structural feature common to various allotropic modifications of tungsten trioxide and several of its hydrates is the presence of $W^{6+}$ in octahedral environment (Figlarz et al 1990). But the great number of possible arrangements of these octahedra, their distortions and the ease of hydration of $\mathrm{WO}_{3}$ either by substitution of one oxygen of the octahedra by $\mathrm{H}_{2} \mathrm{O}$ or by intercalation of $\mathrm{H}_{2} \mathrm{O}$ between the sheets of the layered structure leads to a large number of structures. Among these hydrates the existence and structure of the tungsten trioxide dihydrate and monohydrate are known by the comparison of $\mathrm{MoO}_{3} \cdot 2 \mathrm{H}_{2} \mathrm{O}(\mathrm{Krebs}$ 1972) and $\mathrm{MoO}_{3} \cdot \mathrm{H}_{2} \mathrm{O}$ (Boudjada et al 1993).

In the course of a study on the reactivity of tungsten trioxide hydrates, Gerard et al (1981) obtained a new tungsten trioxide hydrate characterized as $\mathrm{WO}_{3} \cdot 1 / 3 \mathrm{H}_{2} \mathrm{O}$ which had similarities with the sodium octatungstate with large variations in the compositions. This hydrate crystallizes in the orthorhombic system with infinite plane of $\mathrm{WO}_{6}$ octahedra sharing their corners and forming six-membered rings, which had structural relationships with the product of dehydration, a new anhydrous hexagonal tungsten trioxide (Seguin et al 1983). This hexagonal $\mathrm{WO}_{3}$ phase turns irreversibly into the thermodynamically stable monoclinic $\mathrm{WO}_{3}$ phase at about $673 \mathrm{~K}$. A recent investigation involving the preparation and dehydration of $\mathrm{H}_{2} \mathrm{WO}_{4} \cdot \mathrm{H}_{2} \mathrm{O}$ has shown the presence of sodium as a requirement, with a minimum concentration of as much as 160 ppm, for the stabilization of $\mathrm{WO}_{3} \cdot 1 / 3 \mathrm{H}_{2} \mathrm{O}$ (Pfeifer et al 1995). A new form of $\mathrm{WO}_{3}$ with a pyrochlore-type structure was reported by Coucou and Figlarz (1988). This new oxide was prepared in three steps involving the thermal treatment of ammonium tungstate in acidic solution of ethylene glycol. The pyrochlore hydrate, $\mathrm{W}_{2} \mathrm{O}_{6} \cdot x \mathrm{H}_{2} \mathrm{O}$,

*Author for correspondence 
was then obtained by ion exchange in acidic solutions. Dehydration of these hydrates at about $373 \mathrm{~K}$ led to $\mathrm{WO}_{3}$ in the pyrochlore structure.

From $0 \mathrm{~K}$ to $1273 \mathrm{~K}$ stoichiometric tungsten trioxide, $\mathrm{WO}_{3}$, was reported to have undergone many phase transformations in the solid state (Rao and Rao 1974). Below $1173 \mathrm{~K}, \mathrm{WO}_{3}$ was tetragonal in the space group P4/nmm (Kehl et al 1952) and transformed at about $1013 \mathrm{~K}$ into an orthorhombic modification with space group Pmnb. Between $290 \mathrm{~K}$ and $603 \mathrm{~K}, \mathrm{WO}_{3}$ exhibited monoclinic symmetry in the space group $P 2_{1} / n$ (Loopstra and Rietveld 1977). Below $290 \mathrm{~K}, \mathrm{WO}_{3}$ was triclinic with the space group $P 1$ (Diehl et al 1978) and transformed into another monoclinic phase with the space group $P c$ at $233 \mathrm{~K}$. These $\mathrm{WO}_{3}$ related phases had distorted $\mathrm{ReO}_{3}$ type crystal structures in common.

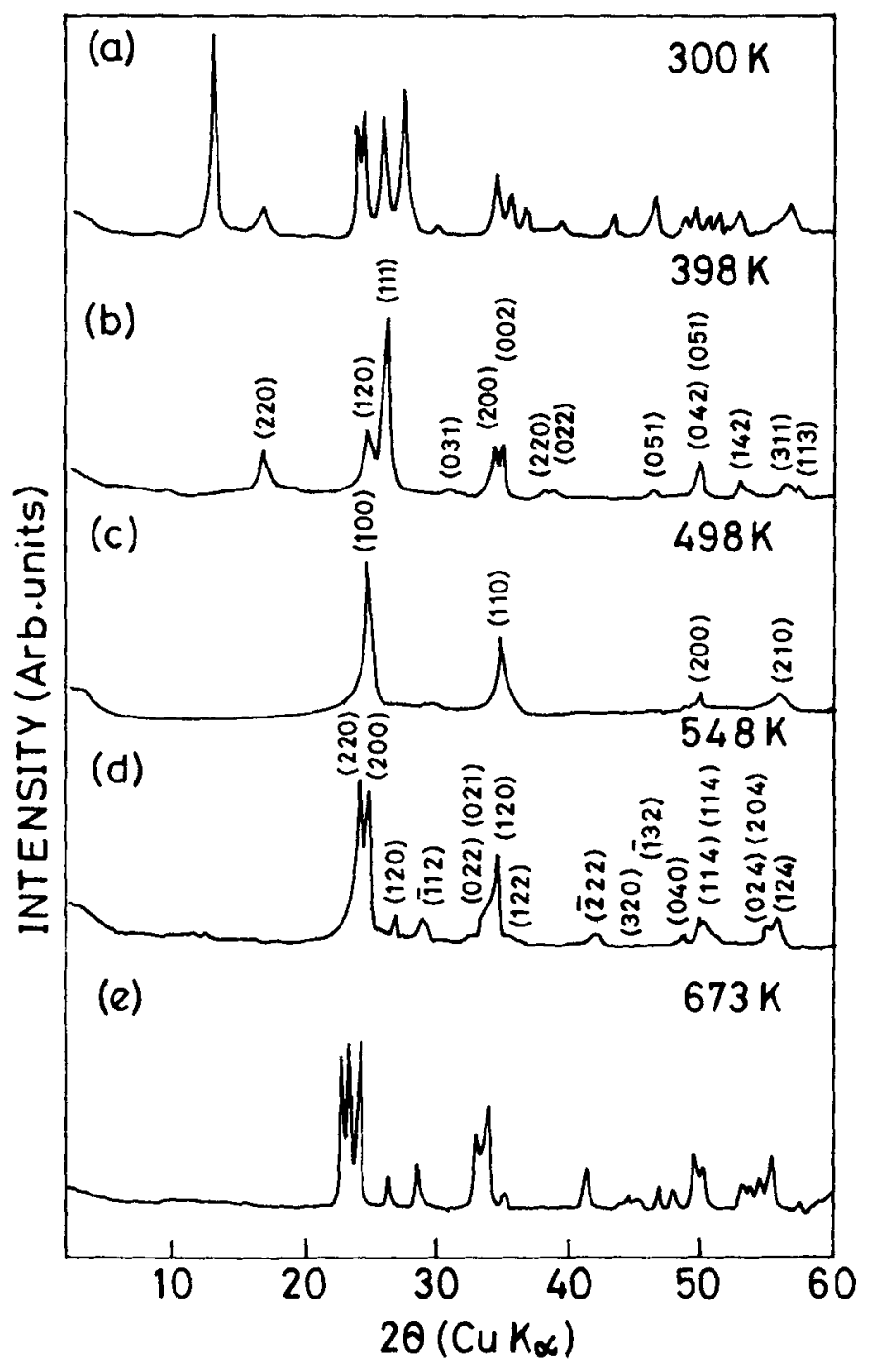

Figure 1. X-ray powder diffraction pattern of (a) $\mathrm{WO}_{3} \cdot 2 \mathrm{H}_{2} \mathrm{O}$, (b) $\mathrm{WO}_{3} \cdot \mathrm{H}_{2} \mathrm{O}$, (c) $\mathrm{WO}_{3} \cdot 036 \mathrm{H}_{2} \mathrm{O}$, (d) $\mathrm{WO}_{3}$ (monoclinic) and (e) $\mathrm{WO}_{3}$ (mixture of monoclinic and triclinic). 
Although the tungstic acids or tungsten trioxide hydrates systems and their dehydration products have been extensively investigated for some time, the existence of some of the intermediate hydrate phases remains to be understood. With this interest, we have carried out the stepwise dehydration of $\mathrm{WO}_{3} \cdot 2 \mathrm{H}_{2} \mathrm{O}$ and studied the topotactic mechanism involved in the reaction.

\section{Experimental}

Preparation of the $\mathrm{WO}_{3} \cdot 2 \mathrm{H}_{2} \mathrm{O}$ was carried out by following the procedure reported by Freedman (1959). Fifty $\mathrm{ml}$ of $1.0 \mathrm{M} \mathrm{Na}_{2} \mathrm{WO}_{4}$ was pippeted into $450 \mathrm{ml}$ of $3.0 \mathrm{~N} \mathrm{HCl}$ at $373 \mathrm{~K}$. The initial yellow solution turned turbid and later to a characteristic yellow precipitate. The mixture was heated for $30 \mathrm{~min}$ and allowed to settle and washed repeatedly with $0.1 \mathrm{~N} \mathrm{HCl}$ at room temperature. The slurry was filtered and dried at $373 \mathrm{~K}$ for $2 \mathrm{~h}$ to obtain orange-yellow powder of $\mathrm{WO}_{3} \cdot 2 \mathrm{H}_{2} \mathrm{O}$. Atomic absorption spectroscopy was performed to confirm the absence of $\mathrm{Na}$ in the final product $(<1$ $\mathrm{ppm}$ ). X-ray diffraction experiments at various temperatures were performed using a STOE/STADIP high resolution powder X-ray diffractometer. Thermogravimetric

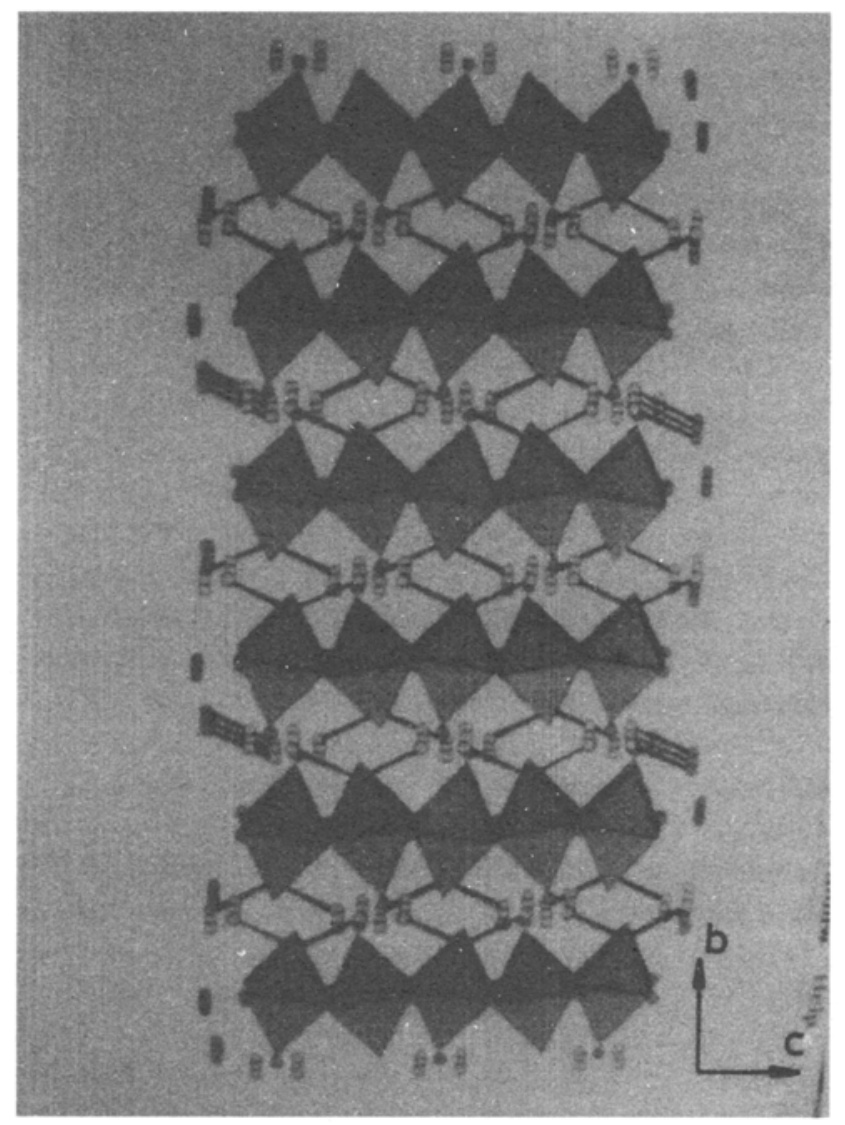

Figure 2. Structural projection of $\mathrm{WO}_{3} \cdot \mathrm{H}_{2} \mathrm{O}$. 
analysis of $\mathrm{WO}_{3} \cdot 2 \mathrm{H}_{2} \mathrm{O}$ and other hydrated products was performed using POLYMER (Model STA 1500) TGA setup. Infrared spectra were recorded using the Perkin-Elmer (Model 580) spectrometer.

\section{Results and discussion}

High-resolution X-ray powder diffraction data of $\mathrm{WO}_{3} \cdot 2 \mathrm{H}_{2} \mathrm{O}$ were collected at various temperatures. Figure 1 shows that at around $398 \mathrm{~K}$ the tungsten trioxide dihydrate looses one $\mathrm{H}_{2} \mathrm{O}$ molecule and converts to $\mathrm{WO}_{3} \cdot \mathrm{H}_{2} \mathrm{O}$. The X-ray diffraction

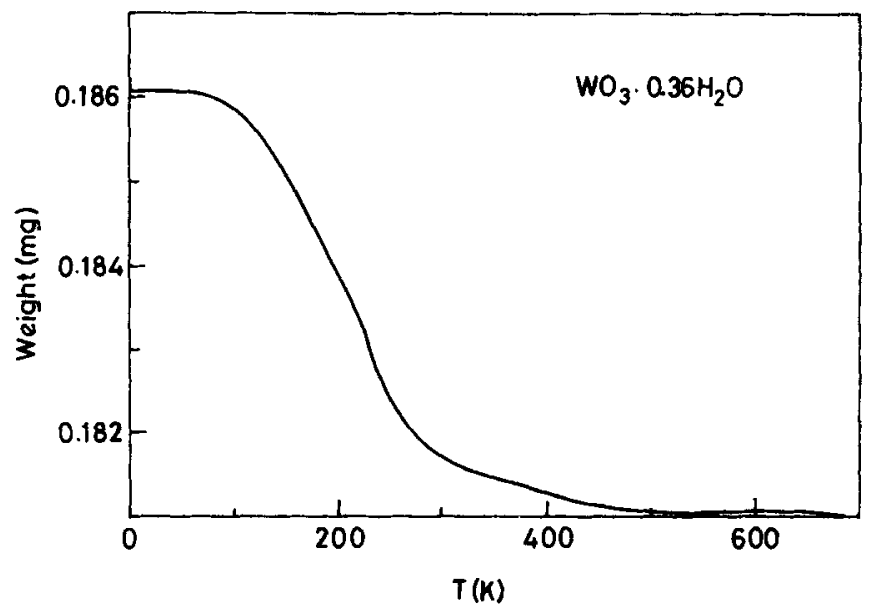

Figure 3. Thermogravimetric analysis plot for $\mathrm{WO}_{3} \cdot 0 \cdot 36 \mathrm{H}_{2} \mathrm{O}$.

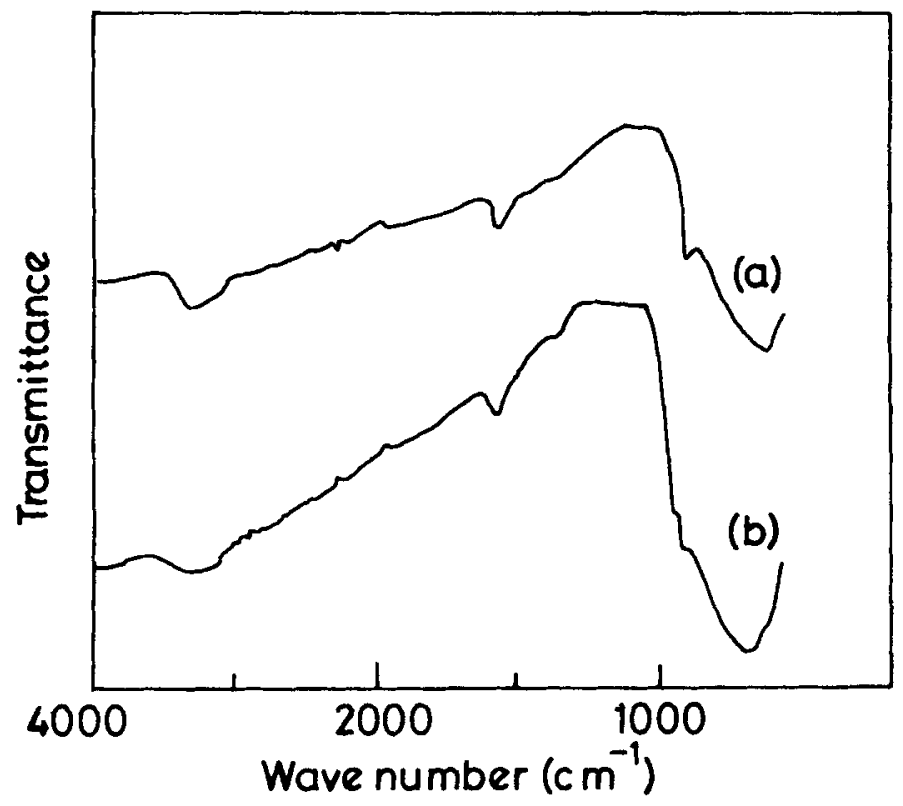

Figure 4. Infrared spectra of (a) $\mathrm{WO}_{3} \cdot \mathrm{H}_{2} \mathrm{O}$ and (b) $\mathrm{WO}_{3} \cdot 0 \cdot 36 \mathrm{H}_{2} \mathrm{O}$. 

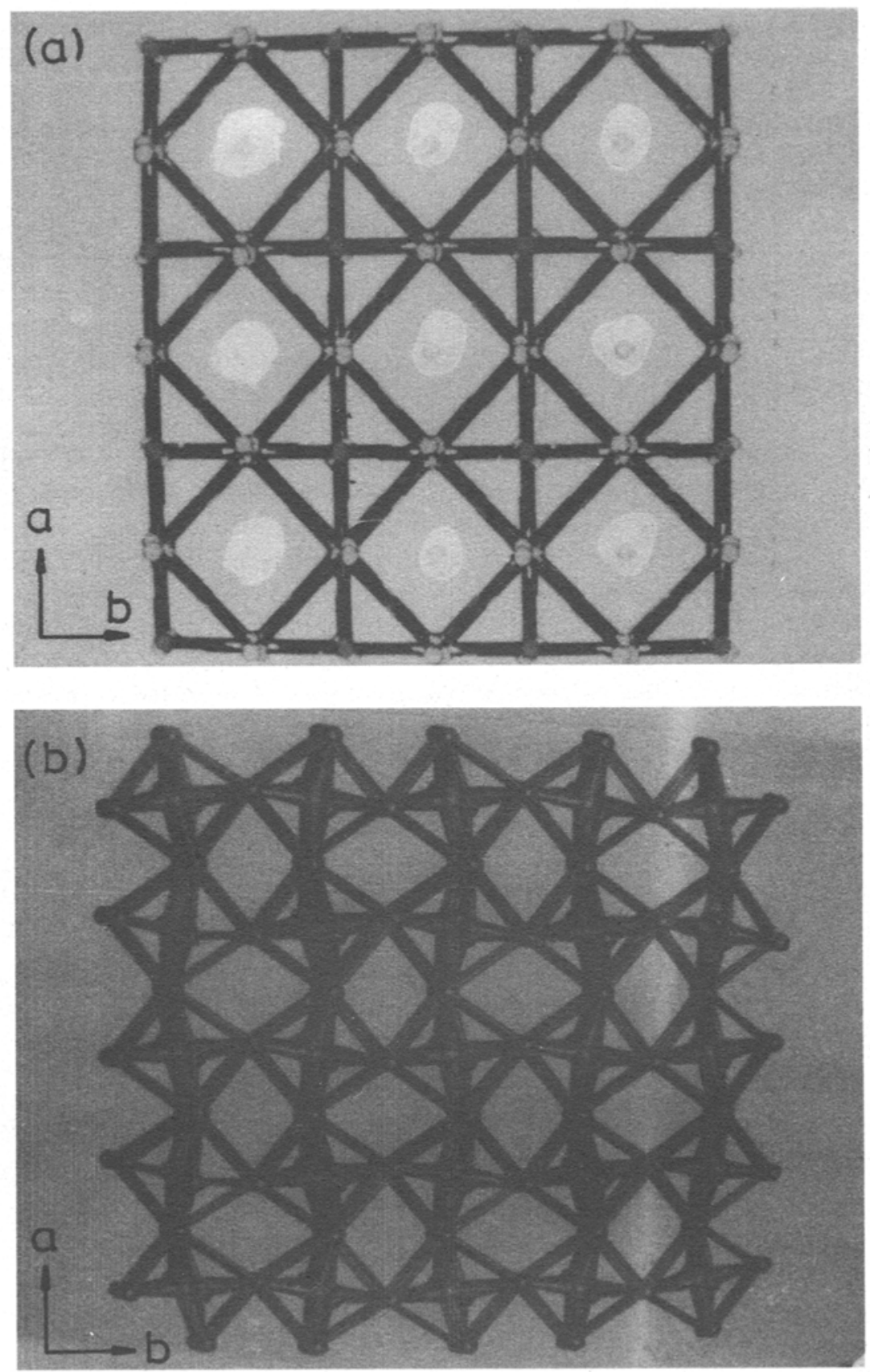

Figure 5. Structural projections of (a) $\mathrm{WO}_{3} \cdot 0 \cdot 36 \mathrm{H}_{2} \mathrm{O}$ and (b) $\mathrm{WO}_{3}$ with monoclinic distortion.

pattern of $\mathrm{WO}_{3} \cdot \mathrm{H}_{2} \mathrm{O}$ (figure $1 \mathrm{~b}$ ) could be indexed in the orthorhombic system (space group Pmnb) (Boudjada et al 1993) with the cell dimensions $\underline{a}=5 \cdot 228, \underline{b}=10 \cdot 680$ and $\underline{c}=5 \cdot 128 \AA$. The structure of $\mathrm{WO}_{3} \cdot \mathrm{H}_{2} \mathrm{O}$ consists of $\mathrm{WO}_{6}$ octahedra which are stacked in sheets at $y=1 / 4$ and $3 / 4$ sharing four corners in the equitorial plane, and the water 
oxygen atoms alternate on the axial corners along [100] and [001] directions (figure 2). All the sheets are linked by hydrogen bonds involving the water molecules and two octahedra of neighbouring sheets. Heating $\mathrm{WO}_{3} \cdot \mathrm{H}_{2} \mathrm{O}$ to $498 \mathrm{~K}$ results in $\mathrm{WO}_{3} \cdot x \mathrm{H}_{2} \mathrm{O}$. The X-ray diffraction pattern of $\mathrm{WO}_{3} \cdot x \mathrm{H}_{2} \mathrm{O}$ (figure $1 \mathrm{c}$ ) could be indexed in the cubic system with the space group $\mathrm{Pm} 3 \mathrm{~m}$ with the cell dimension $\underline{a}=3.675 \AA$.

Thermogravimetric analysis (figure 3) of $\mathrm{WO}_{3} \cdot x \mathrm{H}_{2} \mathrm{O}$ showed weight loss corresponding to 0.36 moles of $\mathrm{H}_{2} \mathrm{O}$ at $575 \mathrm{~K}$. In figure 4, we compare the infrared spectra of $\mathrm{WO}_{3} 0 \cdot 36 \mathrm{H}_{2} \mathrm{O}$ with that of $\mathrm{WO}_{3} \cdot \mathrm{H}_{2} \mathrm{O}$ (Daniel et al 1987). The infrared spectrum of $\mathrm{WO}_{3} \quad 0 \cdot 36 \mathrm{H}_{2} \mathrm{O}$ shows a broad band around $3350 \mathrm{~cm}^{-1}$ corresponding to $\mathrm{O}-\mathrm{H}$ stretching and a pronounced $\mathrm{H}-\mathrm{O}-\mathrm{H}$ deformation band at $1615 \mathrm{~cm}^{-1}$ (figure 4). The $\mathrm{X}$-ray diffraction pattern corresponds to the $\mathrm{ReO}_{3}$ structure consisting of corner linked $\mathrm{WO}_{6}$ octahedra forming an infinite $3 \mathrm{D}$ network of interconnecting tunnels (figure 5a). The structure with layered sheets of $\mathrm{WO}_{6}$ octahedra interleaved with $\mathrm{H}_{2} \mathrm{O}$ molecules in $\mathrm{WO}_{3} \cdot \mathrm{H}_{2} \mathrm{O}$ changes to a structure with a $3 \mathrm{D}$ network of $\mathrm{WO}_{6}$ octahedra in $\mathrm{WO}_{3}$ $0 \cdot 36 \mathrm{H}_{2} \mathrm{O}$. The nature of the coordination of water molecule in $\mathrm{WO}_{3} 0 \cdot 36 \mathrm{H}_{2} \mathrm{O}$ can only be studied through neutron diffraction. Heating $\mathrm{WO}_{3} \cdot 0 \cdot 36 \mathrm{H}_{2} \mathrm{O}$ to $548 \mathrm{~K}$ results in the complete loss of water molecule. The X-ray diffraction pattern of the product heated at $548 \mathrm{~K}$ (figure 1d) corresponds to that of the stable monoclinic $\mathrm{WO}_{3}$ with the space group $P 2_{1} / n$ with the cell dimensions $\underline{a}=7.508, \underline{b}=7.296, \underline{c}=7.691 \AA$ and $\underline{\beta}=90.49^{\circ}$. The structure of the monoclinic phase consists of distorted corner-linked $\mathrm{WO}_{6}$ octahedra with the displacement of tungsten ions from the centre of the octahedra. Further heating of $\mathrm{WO}_{3}$ to $673 \mathrm{~K}$ and then quenching it to room temperature, gives a mixture of monoclinic and triclinic phases (figure 1e). The structural projection with the monoclinic distortion is shown in figure $5 \mathrm{~b}$.

In summary, the present study shows that the thermal dehydration of tungsten trioxide dihydrate proceeds in three steps. All the hydrated and the final dehydrated phases have tungsten in octahedral coordination in common. The intermediate tungsten trioxide with 0.36 moles of water has a cubic symmetry.

\section{Acknowledgements}

The authors thank Prof. C N R Rao for advice and guidance. One of the authors (SA) thanks CSIR, India for the fellowship.

\section{References}

Boudjada N, Rodriguez-Carvajal J, Anne M and Figlarz M 1993 J. Solid State Chem. 105211

Coucou A and Figlarz M 1988 Solid State Ionics 28-30 1726

Daniel M F, Desbat B, Lassegues J C, Gerand B and Figlarz M 1987 J. Solid State Chem. 67235

Diehl R, Brandt $G$ and Salje E 1978 Acta Crystallogr. B34 1105

Figlarz M, Gerard B, Vidal A D, Dumont B, Harb F, Cocou A and Fievet F 1990 Solid State Ionics 43143

Freedman M L $1959 \mathrm{~J}$. Am. Chem. Soc. 813834

Gerard B, Nowogrocki G and Figlarz M 1981 J. Solid State Chem. 38312

Gunter J R 1972 J. Solid State Chem. 5354

Kehl K L, Hay R G and Wahl D 1952 J. Appl. Phys. 23212

Krebs V B 1972 Acta Crystallogr. B28 2222

Loopstra B O and Rietveld H M 1977 Acta Crystallogr. B34 1105 
Pfeifer J, Guifang C, Tekula-Buxbaum P, Kıss B A, Farkas-Jahnke M and Vadasdi K 1995 J. Solid State Chem. 11990

Rao C N R and Rao G V S 1974 Natl. Bur. Stand. 49117

Rao C N R and Raveau B 1995 Transition metal oxides (New York: VCH Publishers, Inc.)

Seguin L, Figlarz M and Pannetier J 1993 Solid State Ionics 63-65 437 